\title{
In vitro Evaluation of Actinobacteria against Tomato Bacterial Wilt (Ralstonia solanacearum EF Smith) in West Showa, Ethiopia
}

\author{
Kassahun Sadessa Biratu ${ }^{1}$, Thangavel Selvaraj ${ }^{2 *}$ and Tariku Hunduma ${ }^{1}$ \\ ${ }^{1}$ Department of Bacteriology, Ambo Plant Protection Research Center, Ambo, Ethiopia \\ ${ }^{2}$ Department of Plant Sciences and Horticulture, College Of Agriculture and Veterinary Sciences, Ambo University, Ambo, Post Box No-19, Ethiopia
}

\begin{abstract}
Ralstonia solanacearum EF Smith is one of the most important and widespread pathogenic bacterium that causes a wilt disease in vegetable crops including tomato (Lycopersicon esculentum Mill.) in West Showa, Ethiopia, mainly in the off-cropping season. In vitro study was conducted to screen indigenous actinobacteria for their antibacterial activity against tomato bacterial wilt pathogen, $R$. solanacearum. 210 soil samples were collected from three districts of West Showa Zone, Ethiopia. Of all soil samples, 86 morphologically distinct actinobacterial isolates were isolated. In the preliminary screening test, 52 isolates were selected showing inhibitory activity against the pathogen and further tested for their antibacterial activity under secondary screening test. In the secondary screening test, all the isolates appeared significantly different $(P \leq 0.05)$ in their inhibition against the target pathogen. Of these isolates, efficient 36 isolates were selected and subjected to the cell free suspension test. All the 36 isolates showed significantly different $(P \leq 0.05)$ in their inhibition activity in the cell free suspension test. In both dual culture and cell free suspension test, totally 21 isolates showed inhibitory activity against the target pathogen. The actinobacterial isolate, Gosu-qoraS\#196-1 had become superior antagonistic isolate against $R$. solanacearum and followed by Awaro S\#174-2, Senkele S\#132-5, Awaro S\#183-1, Senkele S\#133-3, Dhaga file S\#113-1, Awaro S\#176-4, Gabata S\#21-1, Dhaga file S\#128-2 and Awaro S\#174-3 isolates. This study has concluded that the actinobacterial isolates having antibacterial activity against this target pathogen and also the investigated isolates can be used as one component of integrated disease management practice through detailed further test. Then, the further research on the actinobacterial isolates should be focused on species identification, in vivo evaluation of the isolates against tomato bacterial wilt and further testing of its host range.
\end{abstract}

Keywords: Actinobacteria; Screening; Tomato; Bacterial wilt; Ralstonia solanacearum; In vitro

\section{Introduction}

Tomato (Lycopersicon esculentum Mill.) is one of the most widely grown vegetables in the world and it is regarded as one of the top priority vegetable. Tomato contributes to healthy, because it is rich in minerals, essential amino acids, sugars, dietary fibers and it is considered to be fairly high in vitamins, vitamin $\mathrm{C}$, lycopene and betacarotene with potential for better quality processing [1]. In Ethiopia, tomato is one of the most important vegetable crop and its production has shown a marked increase since it became the most profitable crop providing a higher income to small scale farmers compared to other vegetable crops [2]. However, the national average of tomato fruit yield in Ethiopia was often low (125 kg/ha), when compared even to the neighboring African countries like Kenya (164 kg/ha) [2]. Current productivity under farmers' condition in Ethiopia is $190 \mathrm{~kg} / \mathrm{h}$ a whereas yield up to $300 \mathrm{~kg} / \mathrm{ha}$ recorded on research plots [1].

Farmers get lower yield mainly due to diseases, pests and suboptimal fertilization [3]. However, there are a number of factors which limit tomato yield. These include: the lack of improved well performing varieties, poor fruit setting due to heavy rains and excessively high temperature, pests and diseases. In addition to these, fungal as well as bacterial diseases are considered to be the major constraints to tomato production [2]. Howard [4] reported that 10 to $50 \%$ production of tomato were affected by diseases annually. Fungal diseases such as damping-off, crown and root rot, gray mold, blight and powdery mildew and bacterial diseases of wilt and rots are some of the common problems in tomato production. Among those diseases, bacterial wilt (Ralstonia solanacearum EF Smith) of Solanaceous vegetables are the most destructive and widespread disease in tropical and subtropical regions of the world. It is one of the most important and widespread phytopathogenic bacterial wilt pathogen in Ethiopia, mainly in the offcropping season and a destructive disease in vegetable crops including tomato. The percent incidence of tomato bacterial wilt was recorded as high as 55\% [5] in major tomato producing areas of Ethiopia.

The management of tomato against this pathogen is important to maximize the crop's yield. Chemicals either not have direct bactericidal or fungicidal activities against the pathogen or converted into non-toxic derivatives by the pathogen. Management of this disease through chemicals and the use of resistant varieties are possible, but the hazardous impact of agrochemicals on the human health and environments, development of resistant mutants, escalating costs of fumigant pesticides and frequent breakdown of resistant varieties; strongly demand a sustainable and alternative disease management approaches [6].

Many bio-control agents (BCA) have been successfully identified for the control of various plant pathogens as alternative disease

*Corresponding author: Thangavel Selvaraj, Professor of Pathology and Microbiology, Department of Plant Sciences and Horticulture, College of Agriculture and Veterinary Sciences, Ambo University, Ambo, P.O. Box 19, Ethiopia, Tel: +251913073294; Fax: +251-112362037; E-mail: tselvaraj_1956@yahoo.com

Received December 18, 2012; Accepted January 21, 2013; Published January 26, 2013

Citation: Biratu KS, Selvaraj T, Hunduma T (2013) In vitro Evaluation of Actinobacteria against Tomato Bacterial Wilt (Ralstonia solanacearum EF Smith) in West Showa, Ethiopia. J Plant Pathol Microb 4:160. doi:10.4172/21577471.1000160

Copyright: $\odot 2013$ Biratu KS, et al. This is an open-access article distributed under the terms of the Creative Commons Attribution License, which permits unrestricted use, distribution, and reproduction in any medium, provided the original author and source are credited. 
management approaches. Bio-control of pathogenic bacteria has gained considerable attention in the past two decades. Although several bacterial $[7,8]$ bio-control agents for the control of pest and diseases developed and used in the production of vegetables including tomato crops [7]. Among different BCA, actinomycetes which is otherwise called as Actinobacteria or "higher Bacteria" [9] are known a very effective BCA and pesticide sources throughout the world. Actinobacteria play a quite important role in natural ecological system and they are also profile producers of antibiotics, antitumor agents, enzymes, enzyme inhibitors, vitamins, alkaloids and immune modifiers which have been applied in industry, agriculture, forestry and pharmaceutical industries $[10,11]$.

The biodiversity of actinobacterial population density is less common in terrestrial and temperate soils. The actinobacteria are resources under extreme environments (including extreme high and low temperature, extreme high or low $\mathrm{pH}$, high salt concentration etc.) and have received comparatively little attention from pathologists and microbiologists in Ethiopia. The difference in physical and chemical characteristics and the occurrences in the terrestrial and temperate environments of these actinobacteria may helps for their population density, diversity and potential which provide opportunities to a greater extent for the control of bacterial plant diseases [11]. Many studies have been attempted on the isolation of actinobacteria from terrestrial, tropical, sub-tropical and marine sediments [11-13] but not in temperate high mountain soils of Ethiopia.

The biological control of bacterial wilt using bio control agents like actinobacteria have shown a great potential and commercial preparations for the management of such diseases are in use [14]. However, much work still needs to be done in Ethiopia, especially with the bacterial wilt of tomatoes, since the disease is still causing much devastation on the crop. Hence, the present study was carried out to isolate and identify the potential actinobacterial isolates from soils of three different districts of West Showa, Ethiopia, to characterize and screen them to getting some actinobacterial isolates that produce antibiotics and active against tomato bacterial wilt as well as to determine their bio control potential against this test organism through in vitro condition.

\section{Materials and Methods}

\section{Sample collection and isolation of tomato bacterial wilt pathogen}

In this study, the target pathogen was obtained from preserved culture of Ambo Plant Protection Research Center (APPRC), Ambo and the samples of diseased tomato plants were collected from tomato growing areas of the country, mainly around Ziway area of West Showa. For isolation of the pathogen, about $1 \mathrm{~g}$ of the diseased sample was surface sterilized by $1 \%$ hypochlorite and macerated in sterile distilled water and the filtrate was further diluted using sterile distilled water. From the appropriate dilutions, $0.1 \mathrm{ml}$ of an aliquot was spread-plated in duplicates on pre-dried surfaces of Triphenyl Tetrazolium Chloride (TTC) agar medium [15]. After $48 \mathrm{~h}$ of incubation at $30^{\circ} \mathrm{C}$, the typical mummified fluid, slightly red-tinted colonies of $R$. solanacearum was easily distinguished, picked and further purified through repeated streak plating on the same medium. The biochemical characterization such as cytochrome oxidase, catalase [16], $\mathrm{KOH}$ solubility [17], Tween 80 hydrolysis, fatty acid esterase activity [18], starch hydrolysis [18] and pathogenicity (Koch's postulates test) of the target pathogen was tested.

\section{Soil sample collection}

The soil samples were collected from three different districts viz., Tikur Incini, Toke kutaye and Ambo of West Showa, Oromia, Ethiopia (Table 1). In each district, four different kebeles were selected. Nano, Bere, Gabata and Garmama kebeles were selected from Tikur Incini district, Malka Dera, Mutulu-Odobari, Kilinto and Gorfo kebeles were selected from Toke kutaye district and Sankele, Faris, Awaro and Gosu-kora Kebeles were selected from Ambo district. The soil samples were collected from forests, virgin lands, cultivated and grazing lands as stratified random sampling options. Soil samples were randomly collected from top $4 \mathrm{~cm}$ soil profile at an interval of about half a $\mathrm{km}$ between the sampling spots. Soil samples (approx. $200 \mathrm{~g}$ ) were collected in sterile polythene bags, stored in iceboxes and transported to APPRC laboratory, Ambo for further analysis. From all sampling spots, totally about 210 soil samples were collected.

\section{Isolation of actinobacteria from soil samples}

For isolation of actinobacteria, Starch Casein Agar (SCA) medium [19] (soluble starch $10 \mathrm{~g}, \mathrm{~K}_{2} \mathrm{HPO}_{4} 2 \mathrm{~g}, \mathrm{KNO}_{3} 2 \mathrm{~g}, \mathrm{NaCl}_{2} \mathrm{~g}$, casein 0.3 $\mathrm{g}, \mathrm{MgSO}_{4} .7 \mathrm{H}_{2} \mathrm{O} 0.05 \mathrm{~g}, \mathrm{CaCO}_{3} 0.02 \mathrm{~g}, \mathrm{FeSO}_{4} 0.7 \mathrm{H}_{2} \mathrm{O} 0.01 \mathrm{~g}$, agar $20 \mathrm{~g}, \mathrm{pH} 7.2$, distilled water $1000 \mathrm{ml})$ was used. Streptomycin $(40 \mu \mathrm{l} /$ $\mathrm{ml})$ and griseofulvin $(50 \mu \mathrm{l} / \mathrm{ml})$ were used to prevent bacterial and fungal contamination, respectively. Soil samples were serially diluted up to $10^{7}$ and $0.1 \mathrm{ml}$ of aliquots were spreaded over the SCA plates. Actinobacterial colonies were identified by their cultural characteristics, after incubation at 28 to $32^{\circ} \mathrm{C}$ for about 7-14 days, actinobacterial colonies were purified by streak plate technique on cultivation medium.

\section{Characterization of actinobacteria}

Morphology: The actinobacteria were characterized morphologically by the following methods given in the International Streptomyces Project (ISP) [20]. The characters including colony morphology of the isolates such as the color of aerial mycelium (on the surface of agar), reverse side color, production of diffusible pigments [11,12], melanoid and soluble pigments [20] were observed after incubation at $28^{\circ} \mathrm{C}$ for $7-10$ days on SCA. Gram staining [21] and $\mathrm{KOH}$ solubility test [17] were detected on the 7-day old cultures. The microscopic morphology of isolates such as formation of aerial and substrate mycelium and spore arrangement, which are highly characteristic and useful in the identification of actinobactera, were observed by cover slip technique [22] with light microscopy. The color of the colony was compared with standard color chart for identification [23].

\section{Screening of antibacterial activity of actinobacteria}

Preliminary screening: Antibacterial activity of actinobacteria was subjected to primary screening by cross streak plate technique [24]. The pure preserved actinobacterial isolates were reinitiated and used for anti-bacterial activity screening against tomato bacterial wilt. The

\begin{tabular}{|l|l|l|l|l|}
\hline No. & Location/ District & $\begin{array}{l}\text { Number of soil } \\
\text { samples collected }\end{array}$ & Soil type & Soil color \\
\hline 1 & Tikur Incini & 60 & $\begin{array}{l}\text { Sandy loam } \\
\text { Clay loam }\end{array}$ & $\begin{array}{l}\text { Brown } \\
\text { Black } \\
\text { Light black }\end{array}$ \\
\hline 2 & Toke kutaye & 60 & $\begin{array}{l}\text { Silt-loam } \\
\text { Clay-loam }\end{array}$ & $\begin{array}{l}\text { Light red } \\
\text { Brown to red }\end{array}$ \\
\hline 3 & Ambo & 90 & $\begin{array}{l}\text { Clay-loam } \\
\text { Clay }\end{array}$ & $\begin{array}{l}\text { Black } \\
\text { Sticky silt }\end{array}$ \\
\hline & Total & 210 & & \\
\hline
\end{tabular}

Table 1: Soil samples collected from three different districts. 
actinobacterial isolates were streaked on half part of pre-dried surfaces of modified nutrient agar plates and incubated at $30^{\circ} \mathrm{C}$ for $3-5$ days. After observing good growth of the actinobacteria, the target pathogen was streaked at right angles to the streaked growing actinobacteria as close as possible and incubated at $30^{\circ} \mathrm{C}$ for about three days. This screening was done in triplicates for each isolate on Completely Randomized Design (CRD). The inhibitory activity was observed visually daily and actinobacterial isolates showing inhibition to the growth of the target pathogen was selected for further next secondary screening.

Secondary screening: Actinobacterial isolates showing antibacterial activity during preliminary screening was used for the secondary screening step. The actinobacterial isolates were again further tested for their antibacterial activity using modified dual culture technique [25]. In dual culture method, the actinobacterial isolates were spot inoculated on pre-dried surfaces of nutrient agar plates and the plates were incubated at $30^{\circ} \mathrm{C}$ for 3-5 days. After good growth of actinobacteria, $1 \mathrm{ml}$ (about $10^{7} \mathrm{cfu} / \mathrm{ml}$ ) of $24 \mathrm{~h}$ old culture of the test organism from nutrient broth was inoculated on the plates and carefully distributed by rocking. Excess inoculum was carefully removed by tilting the plate at about $45^{\circ} \mathrm{C}$. Standard antibiotic disc, Chloramphenicol $(30 \mu \mathrm{g} / \mathrm{disc})$ was used for comparison. The plates were then incubated at $30^{\circ} \mathrm{C}$ and inhibitory activity of the actinobacteria and the standard antibiotic discs were continuously observed and recorded after 24-72 h. Visually observed zone of inhibition (both diameter and annular radii) was measured from the back side of the plates using calipers. All the plates were replicated three times in CRD. In the same manner as the preliminary screening, actinobacterial isolates showing better/equivalent inhibition zone as visually compared to the standard antibiotic discs were selected for further cell free suspension screening test.

\section{Cell free suspension (CFS) test}

Actinobacterial isolates selected during dual culture were inoculated into SCB and allowed to grow at ambient temperature on a shaker $(120 \mathrm{rpm})$ for about a week until high turbidity was observed. After incubation, the broths were centrifuged twice at $6000 \mathrm{rpm}$ for $30 \mathrm{~min}$ each and then the filtrates were again filtered using microbial filter of $0.22 \mu \mathrm{m}$. Finally, the extracted antimicrobial compounds were aseptically loaded onto $6 \mathrm{~mm}$ diameter sterile disc $(50 \mu \mathrm{l} / \mathrm{disc})$. Then the discs were placed on nutrient agar plates which were pre-seeded with the test organism. Standard Chloramphenicol discs $(30 \mu \mathrm{l} /$ disc $)$ were used as comparison. The plates were then incubated at $30^{\circ} \mathrm{C}$ and inhibitory activity of the actinobacteria and the standard antibiotic discs were continuously observed and recorded after 24-72 h. Visually observed zone of inhibition (both diameter and annular radii) was measured from the back side of the plates using calipers.

\section{Data analyses}

Data were analyzed using SAS version 9.0 (Statistical Analysis System for Windows, 2001-2004, SAS Institute, USA). GLM procedure was followed for data analysis. Means were compared at $5 \%$ significance level, using Duncan's Multiple Range (DMR) test.

\section{Results and Discussion}

\section{Isolation and characterization of the target pathogen}

The target bacterial pathogen was isolated from freshly collected samples at farmers tomato cultivated fields and APPRC isolate culture was compared on the basis of their fluidity, color, and morphological structures. Both isolates produced mummified fluidal of irregular bacterial colonies with the pink color on the TTC agar medium after 48 $\mathrm{h}$ incubation at $30^{\circ} \mathrm{C}$ and were observed for rod shaped after examined under compound microscope. The cultures showed highly mummified fluidal viscous and slight creamy to white color on the TTC medium (Figure 1) and colonies color were showed brown color after $48 \mathrm{~h}$ of incubation at $30^{\circ} \mathrm{C}$. All the isolates produced characteristic whitish on TTC medium and this observation was confirmed with the observation of Kelman [15].

\section{Biochemical characterization of $R$. solanacearum}

All the targeted bacterial pathogen isolates were catalase positive, oxidase positive and $\mathrm{KOH}$ solubility but none of the bacterial isolates showed clear zone during starch hydrolysis test. All the isolates were negative to starch hydrolysis test and were positive to Tween 80 hydrolysis test and also showed an opaque zone of crystals around the colony. The pathogenicity on the artificially inoculated test pieces and symptoms of the disease were also proved.

\section{Isolation and characterization of actinobacteria}

Among 210 soil samples, a total of 86 morphologically distinct and diverse actinobacterial isolates were isolated. Each isolate showed different morphological characteristics based on aerial mass color, reverse side pigments, melanoid and soluble pigments production (Table 2). The colors were recorded using standard color chart as recommended by ISP [20]. Among them, 8 isolates from Tikur Incini district soils which were 9.3\%; 14 isolates from Toke Kutaye district soils which covers $16.28 \%$ and 64 isolates from Ambo district soils encompassing $74.42 \%$ of the total actinobacterial isolates. Common actinobacterial species at all the three different districts were not observed. The identified species (86) were morphologically distinct and were studied upon the aerial, reverse side color, diffusible pigment productions, melanoid and soluble pigments, formation of mycelium and sporophore morphology under microscopic examinations. Similar findings were also previously reported by Kim et al. [26] and Vijayakumar et al. [27]. The soil samples collected from the typical highland of Tikur Incini was almost covering sandy-loam soil types with black color; sandy soil with red to brown color which represents the low land soils collected from Toke kutaye and sand to clay-loam of black soils were stands for soil samples of the Ambo district mid high land i.e. more actinobacterial isolates were isolated from the soils collected from Ambo district. This indicated that actinobacterial isolates are very diverse and occur in diversified terrestrial habitats of cultivated, grazing and forest soils of all lowland, midland and high land of different soil types which were similarly stated by Okami and Hotta [10], as actinobacterial population density was less common in marine sediments relative to terrestrial soils. The soil samples were collected from forests, virgin land, cultivated and grazing lands as stratified
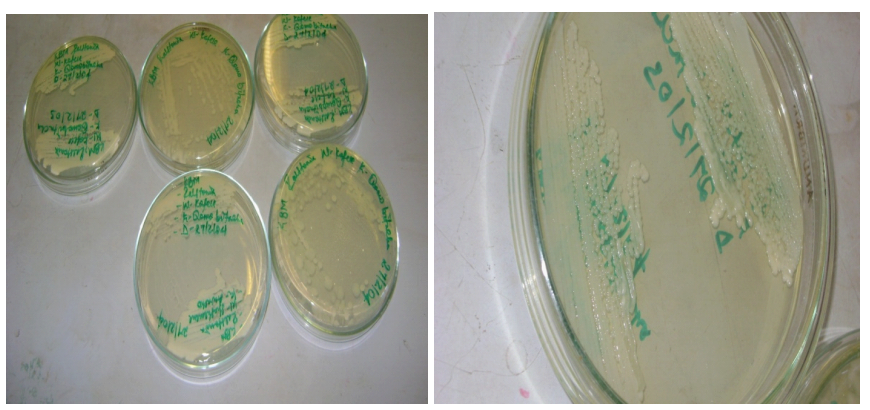

Figure 1: Cultural characteristics of R. solanacearum on TTC medium. 
Citation: Biratu KS, Selvaraj T, Hunduma T (2013) In vitro Evaluation of Actinobacteria against Tomato Bacterial Wilt (Ralstonia solanacearum EF Smith) in West Showa, Ethiopia. J Plant Pathol Microb 4:160. doi:10.4172/2157-7471.1000160

Page 4 of 9

\begin{tabular}{|c|c|c|c|c|c|c|}
\hline No. & Isolate & Aerial mass color & Reverse side color & Diffusible pigments & Melanoid pigments & Soluble pigments \\
\hline 1 & Bere S\#08-1 & Olive & Dark khaki & - & - & - \\
\hline 2 & Bere S\#08-2 & Yellow green & Green yellow & - & + & - \\
\hline 3 & Gabata S\#21-1 & Dark green & Chocolate & - & - & - \\
\hline 4 & Gabata S\#23-1 & Pale green & Dark red & - & - & - \\
\hline 5 & Gabata S\#29-1 & White & Floral white & White & - & - \\
\hline 6 & Malika Dera S\#33-1 & Pale green & Firebrick & - & - & - \\
\hline 7 & Caka malika dera S\#43-1 & Pale green & Firebrick & White & - & - \\
\hline 8 & Caka malika dera S\#54-1 & Olive drab & Firebrick & White & - & - \\
\hline 9 & Gorfo S\#92-1 & Antique white & Dark golden red & - & + & - \\
\hline 10 & Gorfo S\#104-1 & Khaki & Beige & - & - & - \\
\hline 11 & Gorfo S\#106-1 & Dark olive green & Golden red & - & - & - \\
\hline 12 & Gorfo S\#110-1 & Deep yellow & Light green & - & - & - \\
\hline 13 & Gorfo S\#110-2 & Yellow & Dark olive green & - & - & + \\
\hline 14 & Dhaga file S\#113-1 & White & Dark blue & - & - & - \\
\hline 15 & Dhaga file S\#113-2 & Gold & Dark red & - & - & - \\
\hline 16 & Dhaga file S\#121-1 & Forest green & Gold & - & - & - \\
\hline 17 & Dhaga file S\#128-1 & Yellow & Orange & Golden & - & + \\
\hline 18 & Dhaga file S\#128-2 & Violet & Light green & - & - & + \\
\hline 19 & Dhaga file S\#128-3 & Dark olive green & Dark red & Corn silk & - & - \\
\hline 20 & Dhaga file S\#128-4 & Forest green & Red & - & - & + \\
\hline 21 & Dhaga file S\#129-1 & Corn silk & Golden red & - & + & - \\
\hline 22 & Dhaga file S\#130-1 & Dark olive green & Deep red & - & + & - \\
\hline 23 & Dhaga file S\#130-2 & Peru & Firebrick & White & - & - \\
\hline 24 & Senkele S\#132-1 & Dark sea green & Brown & Light white & - & - \\
\hline 25 & Senkele S\#132-2 & Linen & Seashell & - & - & - \\
\hline 26 & Senkele S\#132-3 & Linen & Sandy brown & - & - & - \\
\hline 27 & Senkele S\#132-4 & Rough linon & Moccasin & Navajo white & - & - \\
\hline 28 & Senkele S\#132-5 & Papaya whip & Peach puff & White & + & - \\
\hline 29 & Senkele S\#132-6 & White & Navajo white & - & - & - \\
\hline 30 & Senkele S\#132-7 & Navajo white & Burly wood & - & + & - \\
\hline 31 & Senkele S\#132-8 & Burly wood & Bisque & - & - & - \\
\hline 32 & Senkele S\#132-9 & Bisque & Antique white & - & - & - \\
\hline 33 & Senkele S\#132-10 & Deep white & Wheat & - & - & - \\
\hline 34 & Senkele S\#132-11 & Yellow green & Green & - & - & - \\
\hline 35 & Senkele S\#132-12 & Dark yellow & Gray & - & - & - \\
\hline 36 & Senkele S\#132-13 & Olive & Light salmon & White & - & + \\
\hline 37 & Senkele S\#132-14 & Golden red & Dark golden rod & Burly wood & + & - \\
\hline 38 & Senkele S\#132-15 & Floral white & Dark green & Ghost white & + & - \\
\hline 39 & Senkele S\#132-16 & Ghost white & Red & - & - & + \\
\hline 40 & Senkele S\#133-1 & Brown & Sea green & Ghost white & - & + \\
\hline 41 & Senkele S\#133-2 & Golden red & Golden red & - & + & - \\
\hline 42 & Senkele S\#133-3 & Steal blue & Rosy brown & - & + & - \\
\hline 43 & Senkele S\#142-1 & Dark olive green & Dark orange & - & + & - \\
\hline 44 & Senkele S\# 142-2c & Sea green & Yellow green & - & + & - \\
\hline 45 & Senkele S\# 142-3 & Teal & Tan & - & + & - \\
\hline 46 & Senkele school S\#147-1 & Dark olive green & Brown & - & - & - \\
\hline 47 & Senkele school S\#147-2 & Dark olive green & Dark golden red & - & + & - \\
\hline 48 & Senkele school S\#147-3 & Dark-khaki & Dark golden red & Ghost white & + & - \\
\hline 49 & Senkele school S\#147-4 & Blue violet & Brown & Red & - & + \\
\hline 50 & Senkele school S\#147-5 & Dark olive green & Chocolate & Green & - & - \\
\hline 51 & Senkele school S\#147-6 & Light green & Purple & - & - & + \\
\hline 52 & Senkele school S\#147-7 & Golden red & Dark red & - & - & - \\
\hline 53 & Senkele school S\#147-8 & Yellow & Khaki & - & - & + \\
\hline 54 & Senkele school S\#149-1 & Olive drab & Brown & - & - & - \\
\hline 55 & Senkele school S\#149-2 & Dark red & Firebrick & Red & - & - \\
\hline 56 & Senkele school S\#149-3 & Lime green & Pale violet red & - & + & - \\
\hline 57 & Senkele school S\#149-4 & Medium sea green & Medium violet red & - & + & - \\
\hline 58 & Senkele school S\#149-5 & Olive-green & Red & - & - & + \\
\hline 59 & Senkele school S\#149-6 & Firebrick & Floral white & - & - & - \\
\hline 60 & Senkele school S\#149-7 & Tan & Ivory & - & - & - \\
\hline
\end{tabular}




\begin{tabular}{|c|c|c|c|c|c|c|}
\hline 61 & Farsi S\#156-1 & White & Rough brown & - & - & - \\
\hline 62 & Farsi S\#159-1 & Orange & Purple & Light salmon & - & + \\
\hline 63 & Awaro S\#174-1 & Light white & Navajo white & - & + & - \\
\hline 64 & Awaro S\#174-2 & Olive drab & Maroon & Green & - & - \\
\hline 65 & Awaro S\#174-3 & Yellow green & Sienna & Snow & - & - \\
\hline 66 & Awaro S\#174-4 & Red & Golden yellow & - & - & + \\
\hline 67 & Awaro S\#176-1 & Navajo white & Mint cream & - & + & - \\
\hline 68 & Awaro S\#176-2 & Snow & White & Light white & - & - \\
\hline 69 & Awaro S\#176-3 & Ghost white & Floral white & - & + & - \\
\hline 70 & Awaro S\#176-4 & Sandy brown & Sienna & Red & - & - \\
\hline 71 & Awaro S\#177-1 & White & Purple & Olive-green & - & + \\
\hline 72 & Awaro S\#178-1 & Purple & Golden yellow & Light-yellow & - & - \\
\hline 73 & Awaro S\#178-2 & Golden red & Dim gray & White & + & - \\
\hline 74 & Awaro S\#178-3 & Green & Purple & - & - & + \\
\hline 75 & Awaro S\#183-1 & Tan & Violet red & Green & - & - \\
\hline 76 & Awaro S\#184-1 & Khaki & Orange & - & - & + \\
\hline 77 & Awaro S\#184-2 & Golden rod & Orange & Yellow & - & + \\
\hline 78 & Awaro S\#188-1 & Dark olive green & Dark red & - & - & - \\
\hline 79 & Gosu Qora S\#196-1 & Goldenred & Yellow & White & - & - \\
\hline 80 & Gosu Qora S\#196-2 & Dark olive green & Coral & White & - & - \\
\hline 81 & Gosu Qora S\#201-1 & Deep white & Lemon chiffon & - & + & - \\
\hline 82 & Gosu Qora S\#205-1 & Pale green & Deep red & - & - & - \\
\hline 83 & Gosu Qora S\#205-2 & Ghosh white & Orange & - & - & + \\
\hline 84 & Gosu Qora S\#205-3 & Tan & Yellow & - & - & + \\
\hline 85 & Gosu Qora S\#205-4 & Gray & Moccasin & White & - & - \\
\hline 86 & Ambo Univer. S\#210-1 & Yellow green & Orange & - & - & + \\
\hline
\end{tabular}

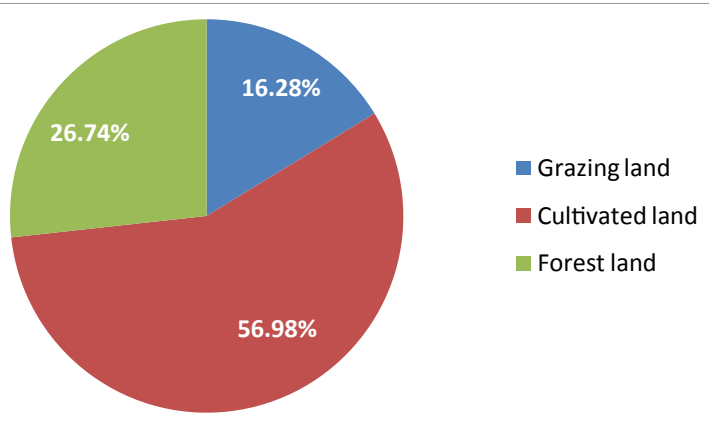

Figure 2: Percentage of actinobacterial isolates isolated from cultivated forest and grazing lands.

random sampling options simply to extend the chance of success of obtaining very distinct actinobacterial isolates. Actinobacteria isolated from forest soil samples were covered $26.74 \%$, cultivated land for $56.98 \%$ and grazing land for $16.28 \%$ (Figure 2), in which 23, 49 and 14 isolates were isolated from forest, cultivated and grazing lands, respectively.

Among 86 actinobacterial isolates, 32 isolates have produced reverse side diffusible pigments, 20 isolates have produced melanoid pigments and 19 isolates produced soluble pigments whereas, 27 isolates produced no reverse side, melanoid and soluble pigments (Figure 3; Table 2) which were similarly reported by Sivakumar [12]; Oskay et al. [14] and Vijayakumar et al. [27]. Morphological characters of the isolates were observed by smears from colonies of 7 day old cultures, stained by Grams' method. Under microscopic examination, all actinobacterial isolates have retained the violet color or not changed to red and were remained Gram-positive bacteria. Likewise, all the actinobacterial isolates were gram positive under $\mathrm{KOH}$ solubility test which is similar with work done by Fahy and Hayward [17].

\section{Screening for antibacterial activity}

Preliminary screening: The preliminary screening was conducted for all 86 actinobacterial isolates against the test pathogen, $R$. solanacearum. Of all the tested isolates, 52 isolates showed inhibition effect to $R$. solanacearum (Figure 4) and were selected for further screening in the secondary test as recommended by Martin and French [28].

Secondary screening: The 52 actinobacterial isolates showing inhibition to the target pathogen during the preliminary screening were further tested for their inhibition using dual culture technique. From the actinobacterial isolates screened by dual culture method, 36 of them were performed effective against tested pathogen in their inhibition activity (Figure 5 and Table 3). Both diameter and annular radius of the inhibition zone were measured and analyzed. All the isolates appeared significantly different $(P \leq 0.05)$ in their inhibition against $R$. solanacearum pathogen. According to the analysis made, there was very highly significance difference among actinobacterial isolates; Gosu qoras\#196-1 which was the superior isolate under this experiment, Awaros\#174-2, Senkeles\#132-5 and Awaros\#183-1 were second, third and fourth antagonistic isolates exhibited more inhibition activity against $R$. solanacearum in their order of inhibition importance (Table 3). Finally, 36 isolates having relatively higher/equal mean of annular radii inhibition zone than control or standard antibiotic disc of Chloramphenicol were selected for their supernatant activity test.

Cell free suspension test screening: From the top performing isolates, 36 of them were again tested using their cell free suspension (Figure 6). Cell free suspension from all the 36 isolates showed significantly different inhibition activity. The actinobacterial isolate, 
Citation: Biratu KS, Selvaraj T, Hunduma T (2013) In vitro Evaluation of Actinobacteria against Tomato Bacterial Wilt (Ralstonia solanacearum EF Smith) in West Showa, Ethiopia. J Plant Pathol Microb 4:160. doi:10.4172/2157-7471.1000160
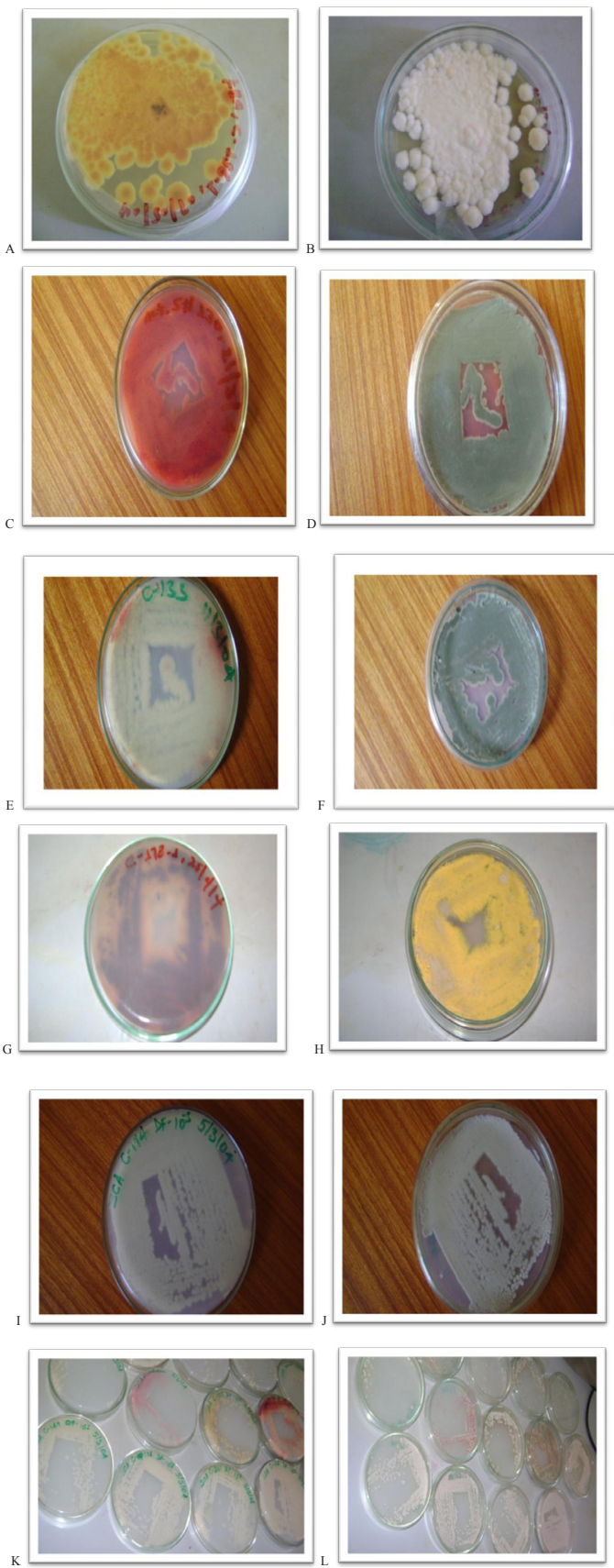

Figure 3: Distinct morphological characteristics of reverse and aerial mycelium color of some actinobacterial Isolates (A) Isolate S\# 176-1 -Reverse side color (B) Isolate S\# 176-1 Aerial mycelium color C) Isolate S\# 130-1 Reverse side color (D) Isolate S\#130-1-Aerial mycelium color (E) Isolate S\#133-1 Reverse side color (F) Isolate S\#133-1- Aerial mycelium color $(\mathrm{G})$ Isolate S\#178-1- Reverse side color $(\mathrm{H})$ Isolate S\#178-1-Aerial mycelium color (I) Isolate S\#174-1- Reverse side color (J) Isolate S\#174-1-Aerial mycelium color (K ) Different actinobacterial isolates- Reverse side color $(\mathrm{L})$ Aerial mycelium color.

Gosu qoras\#196-1 became superior antagonist isolate against $R$. solanacearum and it was very highly significant within and between isolates in mean inter-comparison at $\mathrm{P} \leq 0.05$. There were very highly significant differences between and among very effective and attractive actinobacterial isolates i.e. Awaros\#174-2, Senkeles\#132-5, Awaros\#183-1, Senkeles\#133-3, Dhaga files\#113-1, Awaros\#176-4,
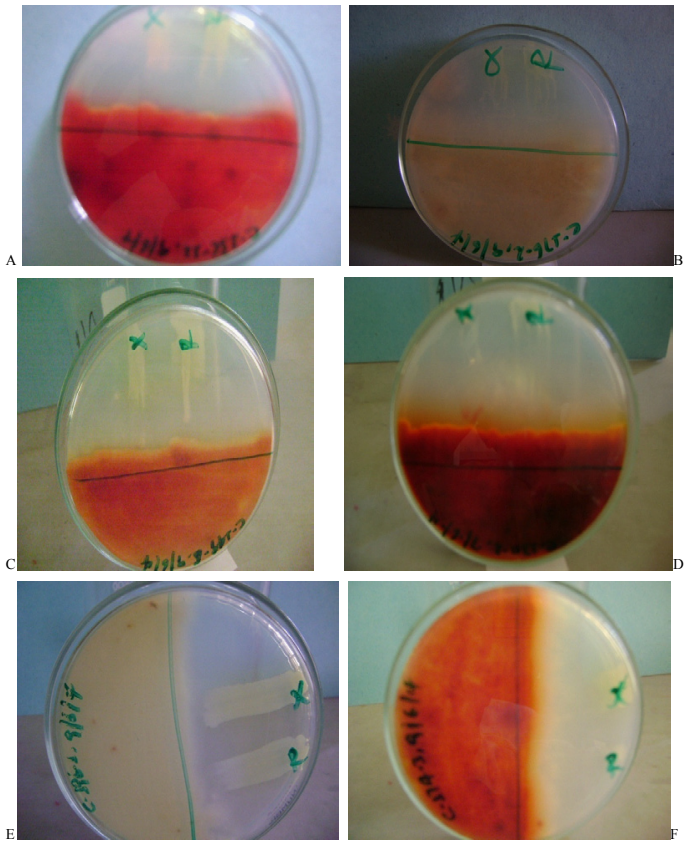

Figure 4: Some actinobacterial Isolates showing inhibition to the target pathogen during Preliminary screening (A) IsolateS\#132-11 (B) IsolateS\#176-2 (C) IsolateS\#149-6 (D) IsolateS\#130-2 (E) IsolateS\#196-1 (F) Isolate S\#174-3, R=Ralstonia solanacearum.
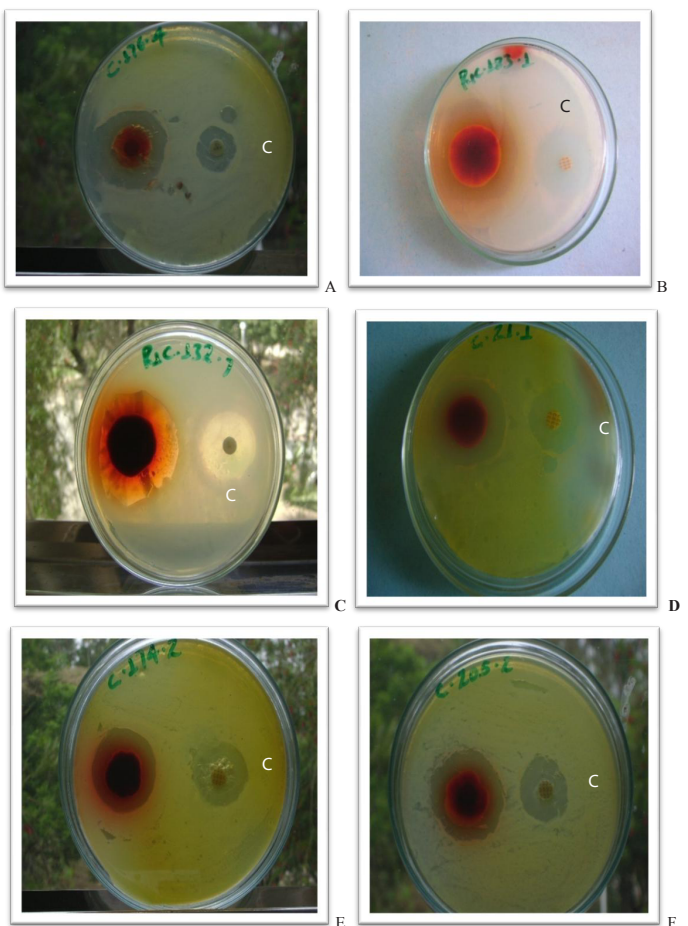

Figure 5: Some Actinobacterial Isolates showing inhibition against

R. solanacearum using dual culture (A) Isolate S\# 176-4 (B) Isolate S\#183-1 (C) Isolate S\#1132-5 (D) Isolate S\#21-1 (E) Isolate S\#174-2 (F) Isolate S\#205-2, C= Chloramphenicol antibiotic standard disc.

Gabatas\#21-1, Dhaga files\#128-2 and Awaros\#174-3; which was $2^{\text {nd }}$, $3^{\text {rd }}, 4^{\text {th }}, 5^{\text {th }}, 6^{\text {th }}, 7^{\text {th }}, 8^{\text {th }}, 9^{\text {th }}$ and $10^{\text {th }}$, respectively in their sequential orders of decreasing inhibition zone observed during mean separation against the test organism (Table 4) and the results obtained were exactly the 
Citation: Biratu KS, Selvaraj T, Hunduma T (2013) In vitro Evaluation of Actinobacteria against Tomato Bacterial Wilt (Ralstonia solanacearum EF Smith) in West Showa, Ethiopia. J Plant Pathol Microb 4:160. doi:10.4172/2157-7471.1000160

\begin{tabular}{|c|c|c|c|c|c|}
\hline \multirow[t]{2}{*}{ No } & \multirow[t]{2}{*}{ Isolates/Treatments } & \multicolumn{3}{|c|}{$\begin{array}{l}\text { Annular Radius of Inhibition } \\
\text { Zone Measured }(\mathrm{mm})\end{array}$} & \multirow{2}{*}{$\begin{array}{l}\text { Mean of Inhibition } \\
\text { Zone of annular } \\
\text { radius }(\mathrm{mm})\end{array}$} \\
\hline & & R1 & $\mathrm{R} 2$ & R3 & \\
\hline 1 & Gosu Qora S\#196-1 & 14.95 & 14.91 & 14.97 & $14.94333 a$ \\
\hline 2 & Awaro S\#174-2 & 14.53 & 14.47 & 14.5 & $14.50000 \mathrm{~b}$ \\
\hline 3 & Senkele S\#132-5 & 13.9 & 13.9 & 13.9 & $13.90000 \mathrm{c}$ \\
\hline 4 & Awaro S\#183-1 & 13.56 & 13.58 & 13.52 & $13.55333 d$ \\
\hline 5 & Senkele S\#133-3 & 13.52 & 13.49 & 13.56 & $13.52333 \mathrm{de}$ \\
\hline 6 & Awaro S\#176-4 & 13.46 & 13.49 & 13.45 & $13.46667 \mathrm{de}$ \\
\hline 7 & Gabata S\#21-1 & 13.42 & 13.39 & 13.4 & $13.40333 \mathrm{e}$ \\
\hline 8 & Awaro S\#174-3 & 13.93 & 13.14 & 13.14 & $13.40333 \mathrm{e}$ \\
\hline 9 & Dhaga file S\#128-2 & 13.37 & 13.41 & 13.38 & $13.38667 e$ \\
\hline 10 & Dhaga file S\#113-1 & 13.1 & 13.02 & 13.07 & $13.06333 f$ \\
\hline 11 & Gabata S\#23-1 & 12.94 & 12.93 & 12.98 & $12.95000 \mathrm{gf}$ \\
\hline 12 & Dhaga file S\#128-1 & 12.83 & 12.83 & 12.83 & $12.83000 \mathrm{gh}$ \\
\hline 13 & Senkele S\#132-2 & 12.84 & 12.83 & 12.81 & 12.82667gh \\
\hline 14 & Dhaga file S\#130-1 & 12.7 & 12.8 & 12.77 & $12.75667 \mathrm{~h}$ \\
\hline 15 & $\begin{array}{l}\text { Senkele school } \\
\text { S\#149-6 }\end{array}$ & 12.6 & 12.61 & 12.64 & $12.61667 i$ \\
\hline 16 & Awaro S\#184-1 & 12.44 & 12.46 & 12.49 & $12.46333 j$ \\
\hline 17 & Ambo UniverS\#210-1 & 10.01 & 12.35 & 12.29 & $12.31667 \mathrm{k}$ \\
\hline 18 & Dhaga file S\#113-2 & 12.23 & 12.24 & 12.24 & 12.23667lk \\
\hline 19 & Senkele S\#133-1 & 12.12 & 12.1 & 12.18 & $12.13333 \mathrm{~lm}$ \\
\hline 20 & Gosu Qora S\#205-2 & 12.11 & 12.11 & 12.14 & $12.12000 \mathrm{Im}$ \\
\hline 21 & $\begin{array}{l}\text { Senkele school } \\
\text { S\#147-3 }\end{array}$ & 12.07 & 12.09 & 12.12 & $12.09333 \mathrm{~m}$ \\
\hline 22 & Awaro S\#184-2 & 11.92 & 11.97 & 11.94 & $11.94333 n$ \\
\hline 23 & Awaro S\#178-1 & 11.92 & 11.9 & 11.96 & $11.92667 n$ \\
\hline 24 & Awaro S\#174-4 & 11.75 & 11.75 & 11.72 & 11.740000 \\
\hline 25 & $\begin{array}{l}\text { Senkele school } \\
\text { S\#149-3 }\end{array}$ & 11.63 & 11.72 & 11.69 & 11.68000po \\
\hline 26 & $\begin{array}{l}\text { Senkele school } \\
\text { S\#147-5 }\end{array}$ & 11.55 & 11.56 & 11.55 & $11.55333 p$ \\
\hline 27 & $\begin{array}{l}\text { Senkele school } \\
\text { S\#147-7 }\end{array}$ & 11.44 & 11.28 & 11.46 & $11.39333 q$ \\
\hline 28 & Bere S\#08-2 & 11.41 & 11.42 & 11.33 & $11.38667 q$ \\
\hline 29 & Malika DeraS\#33-1 & 11.17 & 11.2 & 11.19 & $11.18667 r$ \\
\hline 30 & $\begin{array}{l}\text { Senkele school } \\
\text { S\#149-2 }\end{array}$ & 11.13 & 11.11 & 11.14 & $11.12667 r$ \\
\hline 31 & Senkele S\#132-6 & 11.12 & 11.13 & 11.11 & $11.12000 r$ \\
\hline 32 & $\begin{array}{l}\text { Caka Malika De- } \\
\text { raS\#54-1 }\end{array}$ & 10.72 & 10.69 & 10.71 & $10.70667 s$ \\
\hline 33 & $\begin{array}{l}\text { Senkele school } \\
\text { S\#149-1 }\end{array}$ & 10.48 & 10.44 & 10.46 & $10.46000 t$ \\
\hline 34 & $\begin{array}{l}\text { Senkele school } \\
\text { S\#149-5 }\end{array}$ & 10.44 & 10.37 & 10.44 & $10.41667 t$ \\
\hline 35 & Gosu qoraS\#201-1 & 12.31 & 10.09 & 10.06 & $10.05333 u$ \\
\hline 36 & Gosu qoraS\#110-1 & 9.95 & 9.94 & 9.89 & $9.92667 u$ \\
\hline 37 & $\begin{array}{l}\text { Senkele school } \\
\text { S\#149-4 }\end{array}$ & 9.29 & 9.26 & 9.24 & $9.26333 v$ \\
\hline 38 & $\begin{array}{l}\text { Senkele school } \\
\text { S\#147-6 }\end{array}$ & 9.11 & 9.13 & 9.12 & $9.12000 w$ \\
\hline 39 & Farsi S\#156-1 & 8.91 & 8.89 & 8.93 & $8.91000 x$ \\
\hline 40 & Dhaga file S\#130-2 & 8.72 & 8.74 & 8.76 & $8.74000 y$ \\
\hline 41 & Dhaga file S\#128-3 & 8.52 & 8.56 & 8.51 & $8.53000 z$ \\
\hline 42 & $\begin{array}{l}\text { Senkele school } \\
\text { S\#149-7 }\end{array}$ & 8.31 & 8.28 & 8.3 & 8.29667A \\
\hline 43 & Senkele S\#133-2 & 7.98 & 8.06 & 8.01 & 8.01667B \\
\hline 44 & Awaro S\#176-1 & 7.97 & 7.98 & 7.99 & $7.98000 \mathrm{~B}$ \\
\hline 45 & $\begin{array}{l}\text { Caka malika dera } \\
\text { S\#43-1 }\end{array}$ & 7.91 & 8.05 & 7.93 & 7.96333B \\
\hline 46 & Dhaga file S\#128-4 & 7.07 & 7.13 & 7.08 & $7.09333 C$ \\
\hline 47 & Senkele S\#132-1 & 7.04 & 7.02 & 7 & $7.02000 \mathrm{C}$ \\
\hline 48 & Awaro S\#176-3 & 4.64 & 4.65 & 4.68 & 4.65667D \\
\hline
\end{tabular}

\begin{tabular}{|l|l|l|l|l|l|}
\hline 49 & Senkele S\#132-13 & 4.47 & 4.41 & 4.45 & $4.44333 \mathrm{E}$ \\
\hline 50 & Awaro S\#188-1 & 3.53 & 3.87 & 4.09 & $3.83000 \mathrm{~F}$ \\
\hline 51 & Senkele S\#132-12 & 3.8 & 3.76 & 3.77 & $3.77667 \mathrm{G}$ \\
\hline 52 & Senkele S\#132-3 & 2.41 & 2.38 & 2.41 & $2.40000 \mathrm{G}$ \\
\hline 53 & Standard disc & 10.01 & 9.99 & 10 & $10.000 \mathrm{u}$ \\
\hline
\end{tabular}

Key: $\mathrm{R}=$ replication, Means with the same letter are not significantly different

Table 3: Mean comparison of inhibition zone of actinobacterial isolates against $R$. solanacearum using dual culture method.
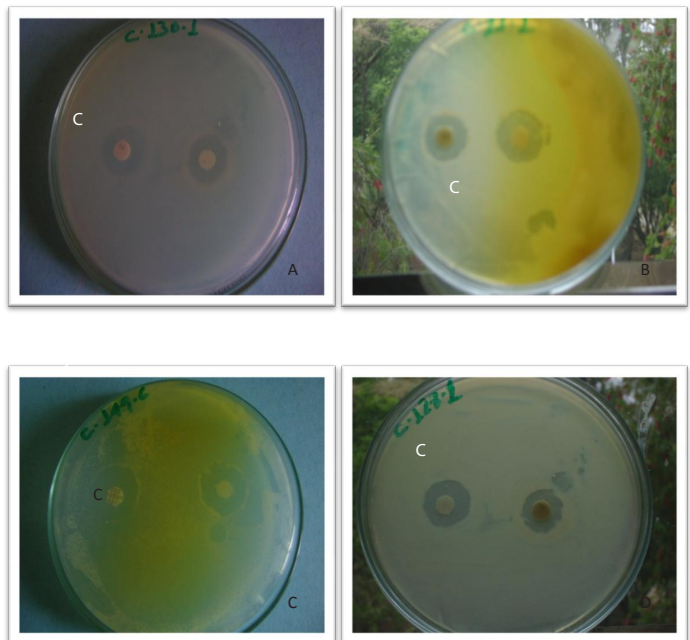

Figure 6: Few Actinobacterial isolates showed best inhibition to the target pathogen under CFS test. $A=$ Isolate $S \# 130-1, B=$ Isolate S\#21-

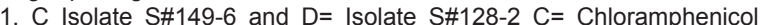
antibiotic standard disc

same with the results of the dual culture experiment and compared (Table 3).

In both dual culture and cell free suspension test, 21 of isolates such as isolate Gosu qoras\#196-1, Awaros\#174-2, Senkeles\#132-5, Awaros\#183-1 and others showed significant differences between actinobacterial isolates (Table 5) and have showed inhibitory activity against the target pathogen and this shows that their inhibitory activity comes from secretion of extracellular antimicrobial compounds as stated by Brock [29]. However, 15 isolates showed very minimal inhibitory activity against the target pathogen and this may indicate that the inhibitory activity during the dual culture test might have come from the competition effect than the secretion of extracellular antimicrobial compounds as the similar work of Brock [29].

\section{Conclusions}

This study concluded that the actinobacterial isolate, GosuqoraS\#196-1 had become superior antagonistic isolate against $R$. solanacearum followed by Awaro S\#174-2, Senkele S\#132-5, Awaro S\#183-1, Senkele S\#133-3, Dhaga file S\#113-1, Awaro S\#176-4, Gabata S\#21-1, Dhaga file S\#128-2 and Awaro S\#174-3 isolates. Therefore, $R$. solanacearum has been controlled successfully by actinobacterial isolates under in vitro condition. In this study, the levels of bio control achieved in laboratory condition by the various isolates of actinobacteria has provide reliable, effective, and alternative management approach to the $R$. solanacearum. This study has investigated actinobacterial isolates having antibacterial activity against this target pathogen, from these very few samples indicating that actinobacteria from Ethiopian ecology can be a good potential for investigation of bioactive metabolites for 
Citation: Biratu KS, Selvaraj T, Hunduma T (2013) In vitro Evaluation of Actinobacteria against Tomato Bacterial Wilt (Ralstonia solanacearum EF Smith) in West Showa, Ethiopia. J Plant Pathol Microb 4:160. doi:10.4172/2157-7471.1000160

\begin{tabular}{|c|c|c|c|c|c|}
\hline \multirow[t]{2}{*}{ No. } & \multirow[t]{2}{*}{ Isolates/Treatments } & \multicolumn{3}{|c|}{$\begin{array}{l}\text { Annular Radius of Inhibition } \\
\text { Zone Measured }(\mathrm{mm})\end{array}$} & \multirow{2}{*}{$\begin{array}{l}\text { Mean of Inhibition } \\
\text { Zone of annular } \\
\text { radius }(\mathrm{mm})\end{array}$} \\
\hline & & $R 1$ & $R 2$ & $R 3$ & \\
\hline 1 & Gosu qoraS\#196-1 & 8.44 & 8.4 & 8.41 & $8.41667 a$ \\
\hline 2 & Awaro S\#174-2 & 8.36 & 8.35 & 8.37 & $8.36000 b$ \\
\hline 3 & Senkele S\#132-5 & 8.13 & 8.12 & 8.12 & $8.12333 c$ \\
\hline 4 & Awaro S\#183-1 & 7.45 & 7.46 & 7.47 & $7.46000 d$ \\
\hline 5 & Senkele S\#133-3 & 7.41 & 7.43 & 7.44 & $7.42667 e$ \\
\hline 6 & Dhaga file S\#113-1 & 7.38 & 7.4 & 7.41 & 7.39667e \\
\hline 7 & Awaro S\#176-4 & 7.12 & 7.12 & 7.1 & $7.11333 f$ \\
\hline 8 & Gabata S\#21-1 & 7.08 & 7.05 & 7.07 & $7.06667 \mathrm{~g}$ \\
\hline 9 & Dhaga file S\#128-2 & 6.99 & 6.98 & 6.97 & $6.98000 \mathrm{~h}$ \\
\hline 10 & Awaro S\#174-3 & 6.89 & 6.9 & 6.93 & $6.90667 i$ \\
\hline 11 & Gabata S\#23-1 & 6.89 & 6.9 & 6.88 & $6.89000 i$ \\
\hline 12 & Dhaga file S\#128-1 & 6.77 & 6.76 & 6.76 & $6.76333 j$ \\
\hline 13 & Senkele S\#132-2 & 6.55 & 6.58 & 6.53 & $6.55333 k$ \\
\hline 14 & Dhaga file S\#130-1 & 6.36 & 6.37 & 6.34 & $6.35667 m$ \\
\hline 15 & Senkele school S\#149-6 & 6.33 & 6.33 & 6.3 & $6.32000 n$ \\
\hline 16 & Awaro S\#184-1 & 6.28 & 6.26 & 6.29 & 6.276670 \\
\hline 17 & Ambo UniverS\#210-1 & 6.27 & 6.29 & 6.26 & 6.273330 \\
\hline 18 & Dhaga file S\#113-2 & 6.25 & 6.25 & 6.27 & 6.256670 \\
\hline 19 & Senkele S\#133-1 & 6.11 & 6.1 & 6.12 & $6.11000 p$ \\
\hline 20 & Gosu qoraS\#205-2 & 6.09 & 6.1 & 6.11 & $6.10000 p$ \\
\hline 21 & Senkele school S\#147-3 & 5.4 & 5.41 & 5.43 & $5.41333 q$ \\
\hline 22 & Standard disc & 6.5 & 6.51 & 6.49 & 6.500001 \\
\hline 23 & Senkele school S\#147-7 & 5.39 & 5.38 & 5.4 & $5.39000 q$ \\
\hline 24 & Awaro S\#178-1 & 5.31 & 5.32 & 5.34 & $5.32333 r$ \\
\hline 25 & Awaro S\#174-4 & 5.2 & 5.25 & 5.18 & $5.21000 \mathrm{~s}$ \\
\hline 26 & Senkele school S\#149-3 & 5.04 & 5.09 & 5.11 & $5.08000 t$ \\
\hline 27 & Bere S\#08-2 & 4.87 & 4.90 & 4.92 & $4.89667 u$ \\
\hline 28 & Senkele school S\#147-5 & 4.78 & 4.77 & 4.82 & $4.79000 v$ \\
\hline 29 & Malika DeraS\#33-1 & 4.2 & 4.23 & 4.27 & $4.23333 w$ \\
\hline 30 & Senkele school S\#149-5 & 3.89 & 3.94 & 3.91 & $3.91333 x$ \\
\hline 31 & Senkele school S\#149-1 & 3.22 & 3.2 & 3.28 & $3.23333 y$ \\
\hline 32 & Senkele school S\#149-2 & 3.01 & 2.98 & 2.99 & $2.99333 z$ \\
\hline 33 & $\begin{array}{l}\text { Caka Malika De- } \\
\text { raS\#54-1 }\end{array}$ & 2.42 & 2.4 & 2.44 & $2.42000 A$ \\
\hline 34 & Senkele S\#132-6 & 1.2 & 1.26 & 1.25 & $1.23667 B$ \\
\hline 35 & Gosu qoraS\#201-1 & 1.02 & 1.03 & 1.05 & $1.03333 \mathrm{C}$ \\
\hline 36 & Gosu qoraS\#110-1 & 0 & 0 & 0 & $0.00000 D$ \\
\hline 37 & Awaro S\#184-2 & 0 & 0 & 0 & $0.00000 D$ \\
\hline
\end{tabular}

Key: $\mathrm{R}=$ replication, Means with the same letter are not significantly different

Table 4: Inhibition effect of actinobacterial isolates against test organism by CFS test.

further use. The investigated isolates can be used as one component of integrated disease management practice through detailed further test. More research is also needed on the formulation and delivery of the actinobacteria bio control agent's preparations. Further research on the actinobacterial isolates should be focused on species identification, in vivo evaluation and further testing of its host range and disease controlling capabilities in other pathogens. The strong inhibition of actinobacteria to bacterial pathogen, Ralstonia solanacearum justifies the need for evaluating its potential as bio control agents for controlling a wider range of pathogens.

\section{Acknowledgements}

I am greatly indebted to my advisors Prof. Thangavel Selvaraj and Tariku Hunduma for their invaluable professional help initiatives and encouragement. This research work also could have been realized without the consistent support of the whole staff of Ambo Plant Protection Research Center (APPRC) and the Department of Plant Sciences of Ambo University, Ambo, Ethiopia.

\begin{tabular}{|c|c|c|c|}
\hline No & Isolates & $\begin{array}{l}\text { Mean of Annular radius } \\
\text { of Dual Culture Inhibition } \\
\text { Zone }(\mathrm{mm})\end{array}$ & $\begin{array}{l}\text { Mean of Annular radius } \\
\text { of CFS Inhibition Zone } \\
(\mathrm{mm})\end{array}$ \\
\hline 1 & Gosu qoraS\#196-1 & 14.94333a & $8.41667 a$ \\
\hline 2 & Awaro S\#174-2 & $14.50000 \mathrm{~b}$ & $8.36000 \mathrm{~b}$ \\
\hline 3 & Senkele S\#132-5 & $13.90000 \mathrm{c}$ & $8.12333 c$ \\
\hline 4 & Awaro S\#183-1 & $13.55333 d$ & $7.46000 d$ \\
\hline 5 & Senkele S\#133-3 & 13.52333de & $7.42667 e$ \\
\hline 6 & Dhaga file S\#113-1 & $13.06333 f$ & 7.39667e \\
\hline 7 & Awaro S\#176-4 & $13.46667 \mathrm{de}$ & $7.11333 f$ \\
\hline 8 & Gabata S\#21-1 & $13.40333 e$ & $7.06667 \mathrm{~g}$ \\
\hline 9 & Dhaga file S\#128-2 & $13.38667 \mathrm{e}$ & $6.98000 \mathrm{~h}$ \\
\hline 10 & Awaro S\#174-3 & $13.40333 \mathrm{e}$ & $6.90667 i$ \\
\hline 11 & Gabata S\#23-1 & $12.95000 \mathrm{gf}$ & $6.89000 \mathrm{i}$ \\
\hline 12 & Dhaga file S\#128-1 & $12.83000 \mathrm{gh}$ & $6.76333 \mathrm{j}$ \\
\hline 13 & Senkele S\#132-2 & 12.82667gh & $6.55333 \mathrm{k}$ \\
\hline 14 & Dhaga file S\#130-1 & $12.75667 \mathrm{~h}$ & $6.35667 \mathrm{~m}$ \\
\hline 15 & Senkele school S\#149-6 & $12.61667 i$ & $6.32000 n$ \\
\hline 16 & Awaro S\#184-1 & 12.46333j & 6.276670 \\
\hline 17 & Ambo UniverS\#210-1 & $12.31667 \mathrm{k}$ & 6.273330 \\
\hline 18 & Dhaga file S\#113-2 & $12.23667 \mathrm{lk}$ & 6.25667 o \\
\hline 19 & Senkele S\#133-1 & $12.13333 \mathrm{~lm}$ & $6.11000 p$ \\
\hline 20 & Gosu qoraS\#205-2 & 12.12000Im & $6.10000 p$ \\
\hline 21 & Senkele school S\#147-3 & $12.09333 \mathrm{~m}$ & $5.41333 q$ \\
\hline 22 & Standard disc & $10.000 u$ & 6.500001 \\
\hline 23 & Senkele school S\#147-7 & $11.39333 q$ & $5.39000 q$ \\
\hline 24 & Awaro S\#178-1 & $11.92667 n$ & $5.32333 r$ \\
\hline 25 & Awaro S\#174-4 & $11.74000 \circ$ & $5.21000 s$ \\
\hline 26 & Senkele school S\#149-3 & 11.68000po & $5.08000 \mathrm{t}$ \\
\hline 27 & Bere S\#08-2 & $11.38667 q$ & $4.89667 u$ \\
\hline 28 & Senkele school S\#147-5 & $11.55333 p$ & $4.79000 v$ \\
\hline 29 & Malika DeraS\#33-1 & $11.18667 r$ & $4.23333 w$ \\
\hline 30 & Senkele school S\#149-5 & $10.41667 t$ & $3.91333 x$ \\
\hline 31 & Senkele school S\#149-1 & $10.46000 \mathrm{t}$ & $3.23333 y$ \\
\hline 32 & Senkele school S\#149-2 & $11.12667 r$ & $2.99333 z$ \\
\hline 33 & Caka Malika DeraS\#51 & 10.70667s & $2.42000 a$ \\
\hline 34 & Senkele S\#132-6 & $11.12000 r$ & $1.23667 b$ \\
\hline 35 & Gosu qoraS\#201-1 & $10.05333 u$ & $1.03333 c$ \\
\hline 36 & Gosu qoraS\#110-1 & $9.92667 u$ & $0.00000 d$ \\
\hline 37 & Awaro S\#184-2 & $11.94333 n$ & $0.000000 d$ \\
\hline
\end{tabular}

Means with the same letters are not significantly different

Table 5: Mean of inhibition zone comparison for actinobacterial isolates showing inhibitory activity both during dual culture and cell free suspension test.

\section{References}

1. Naika S, Jeude JL, Goffau M, Hilmi M, Dam B (2005) Cultivation of Tomato: Production, Processing and Marketing. Agromisa Foundation and CTA Wageningen, Netherlands.

2. Lemma D, Yayeh Z, Herath M (1992) Agronomic studies in tomato. Horticulture Research and Development in Ethiopia: Proceedings of the Second National Horticultural Workshop of Ethiopia. Addis Ababa, Ethiopia.

3. Tesfaye B (2008) Response of tomato cultivars differing in growth habit to nitrogen and phosphorus fertilizers and spacing on vertisol in Ethiopia. Acta Agric Slov 91: 103-119.

4. Howard RJ (1994) Diseases and Pests of Greenhouse Crops. In: Garland JA and Seaman WL. (Eds.). Diseases and pests of vegetable crops in Canada. The Canadian Phytopathological and Entomological Society of Canada. 303305.

5. Ethiopian Agricultural Research Organization (EARO) (2002). EARO Annual Report 2000, Addis Ababa, Ethiopia.

6. Pleban S, Ingel F, Chet I (1995) Control of Rhizoctonia solani and Sclerotium 
Citation: Biratu KS, Selvaraj T, Hunduma T (2013) In vitro Evaluation of Actinobacteria against Tomato Bacterial Wilt (Ralstonia solanacearum EF Smith) in West Showa, Ethiopia. J Plant Pathol Microb 4:160. doi:10.4172/2157-7471.1000160

rolfsii in the greenhouse using endophytic Bacillus spp. Eur J Plant Pathol 101: 665-672.

7. Becker JO, Schwinn FJ (1993) Control of soil-borne pathogens with living bacteria and fungi: Status and outlook. Pesticide Science 37: 355-363.

8. Harris AR, Schisler DA, Correll RL, Ryder MH (1994) Soil bacteria selected for suppression of Rhizoctonia solani, and growth promotion in bedding plants. Soil Biol Biochem 26: 1249-1255

9. Kathiresan K, Balagurunathan R, Selvam MM (2005) Fungicidal activity of marine actinomycetes against phytopathogenic fungi. Indian J Biotechnol 4 271-276.

10. Okami Y, Hotta K (1988) Search and discovery of new antibiotics. In M. Goodfellow ST, Williams M, Mordarski (Eds.). Actinomycetes in biotechnology. Academic Press, London.

11. Vijayakumar R, Muthukumar C, Thajuddin N, Panneerselvam A, Saravanamuthu $R$ (2009) Isolation and characterization of antagonistic actinomycetes from Coimbatore soils, Tamil Nadu, India. International Journal of Scientific Transactions in Environment and Technovation 2: 191-201.

12. Sivakumar K (2001) Actinomycetes of an Indian mangrove environment: An inventory, Annamalai University, Chidambaram, Tamil Nadu, India.

13. Saritha K, Jeyachandran S (2011) Isolation and characterization of antagonistic Streptomycetes from marine sediments. J Pure App Microbiol 5: 111-116.

14. Oskay AM, Usame T, Cem A (2004) Antibacterial activity of some actinomycetes isolated from farming soils of Turkey. Afr J Biotechnol 3: 441-446.

15. Kelman A (1954) The relationship of Pathogenicity of Pseudomonas solanacearum to colony appearance on a tetrazolium medium. Phytopathology 44: 693-695

16. He LY, Sequeira L, Kelman A (1983) Characteristics of strains of Pseudomonas solanacearum from China. Plant Dis 67: 1357-1361.

17. Fahy PC, Hayward AC (1983) Media and methods for isolation and diagnostic tests. In. Klement Z, Rudolph K, Sands DC, (Eds). Methods in Phytobacteriology. Akademiai Kiado, Budapest,Hungary.
18. Sands DC (1990). Physiological Criteria-Determinative Tests. In. Klement Z, Rudolph K, Sands DC, (Eds). Methods in Phytobacteriology. Akademiai Kiado Budapest, Hungary.

19. Kuster E, Williams ST (1964) Selection of media for Isolation of Streptomycetes Nature 202: 928-929.

20. Shirling EB, Gottlieb D (1966) Methods for characterization of Streptomyces species. Int J Syst Bacteriol 16: 313-340.

21. Hucker GJ, Conn HJ (1923) Methods of Gram stainning. Technical Bulletin No. 93. New York Agricultural Experiment Station.

22. Nolan R, Cross N (1988) Isolation and screening of actinomycetes. In Actinomycetes in Biotechnology. (Eds.) M. Goodfellow ST, Williams SR, Mordarski M, Academic Press, London.

23. Pridham TG (1965) Color and Streptomyces Report of an International Workshop on Determination of Color of Streptomycetes. Appl Environ Microbiol 13: 43-61.

24. Egorov NS (1987) Antibiotics, a scientific approach. Mir publishers, Moscow.

25. Behal V (2000) Bioactive products from Streptomyces. Adv Appl Microbiol 47: 113-156.

26. Kim CJ, Lee KH, Shimazu A, Yoo ID (1994) Re-isolation, frequency of Soil actinomycetes on multiple isolation. Midia Kor J Appl Microbial Biotechnology 22: $329-330$.

27. Vijayakumar R, Muthukumar C, Thajuddin N, PanneerselvamA, Saravanamuthu $R$ (2007) Studies on the diversity of actinomycetes in the Palk Strait region of Bay of Bengal, India. Actinomycetologica 21: 59-65.

28. Martin C, French ER (1985) Bacterial wilt of potato: Pseudomonas solanacearum. Technical information Bulletin 13. International Potato Center, Lima, Peru.

29. Brock TD (2009) Biology of Microorganisms, (12thedn). Pearson Benjamin Cummings. 